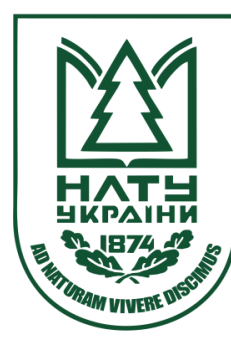

Науковий вісник НлТУ України

Scientific Bulletin of UNFU

ISSN 1994-7836 (print)

https://nv.nltu.edu.ua

https://doi.org/10.15421/40280602

Article received 15.06.2018 p.

Article accepted 25.06.2018 p.

УДК 712.3:58.006

$@ \bowtie$ Correspondence author

L. V. Vegera

lyudmila1vegera@gmail.com

Л. В. Вегера ${ }^{1}$ В. Д. Мазуренко ${ }^{2}$

${ }^{1}$ Національний дендрологічний парк "Софївка", НАН України, м. Умань, Україна

${ }^{2}$ Уманський наиіональний університет садівництва, м. Умань, Україна

\title{
СТВОРЕННЯ СТІЙКИХ ФІТОЦЕНОЗІВ РОДОДЕНДРОНОВИХ САДІВ В УМОВАХ УКРАЇНИ: ПЕРЕДУМОВИ ТА ПІДХОДИ
}

\begin{abstract}
3'ясовано основні передумови створення стійких високодекоративних фітоценозів рододендронових садів у грунтовокліматичних умовах України. Узагальнено дані літературних джерел і власних досліджень щодо створення садів рододендронів в Україні. Наголошено, що перші сади рододендронів на теренах України виникли у XX ст. у ботанічних садах як наслідок інтродукційної роботи ботанічних установ, коли відбувалось стрімке збільшення колекційного фонду деревних рослин, зокрема і родини Ericaceae DC. та іiі найчисленнішого роду Rhododendron L. Висвітлено такі принципи формування та створення садів за участю рододендронів, як фітоценотичний та фізіономічний. Фітоценотичний принцип підбору рослин для формування насаджень базується на фітоценологічному вченні про сумісний ріст рослин у природі, їх склад і взаємовплив. У культурних ценозах України пейзажні картини рододендрового саду бажано створювати передусім 3 деревними породами, з якими вони як підлісок ростуть у природних умовах, а саме із сосною, модриною, дубом, вільхою та іншими породами із глибокою кореневою системою. Під час добору рододендронів за фізіономічним принципом потрібно враховувати силу росту та форму крони кущів, сезонну динаміку. Однак тільки комплексне застосування названих принципів у поєднанні з екологічним може сприяти підвищенню декоративності саду та адаптаційних властивостей рододендронів в умовах України.
\end{abstract}

Ключові слова: фітоценотичний; фізіономічний принципи; Rhododendron L.; застосування; адаптаційні властивості.

Вступ. Сад завжди подібний до творчої майстерні, в якій садівник прагне поєднати особливий стиль планування композицій 3 дерев, кущів і квітів, намагаючись створити в саду картину краси та гармонії завдяки вдалому поєднанню форм і кольорів. Тоді, залежно від пір року, садом можна милуватись у будь-яку пору року: навесні і влітку - красою бруньок, що розпускаються, неповторним цвітінням і різними відтінками зеленого листя, восени - оригінальними плодами і золотими або багряними листками, взимку - формою крони та візерунками стовбурів дерев.

Відомо, що у створенні європейських і азійських садів рододендрони відіграють особливу роль, задовольняючи творчу фантазію і вишукані смаки ландшафтних архітекторів. Завдяки різноманіттю їх екологічних типів представники роду Rhododendron L. можна використовувати для створення високодекоративних композицій у різних кліматичних зонах України.

На погляд відомого дендролога-рододендриста ботанічного саду ім. О. В. Фоміна А. У. Зарубенка, збагачення культурної флори України новими видами, формами та сортами рослин, зокрема гарно квітучими кущами, - важливе завдання ботанічних садів і дендропарків як наукових установ, які покликані інтродукувати рослини. Рододендрони цілком можуть задовольнити потреби названих установ у вирішенні цього питан- ня. Завдяки інтродукції рододендрони збільшують та вдосконалюють асортимент високодекоративних кущів 3 подальшим використанням їх у декоративному садівництві та інших галузях національного господарства (Zarubenko, 2006).

Перевага використання рододендронів для створення садів перед іншими декоративними кущами полягає в тому, що вони вирізняються наявністю листопадних, вічнозелених і напіввічнозелених таксонів, величиною, формою і широкою гамою кольорів квіток, величиною і формою листків, габітусом, різними строками цвітіння (Kohno, 2002).

Мета дослідження - з'ясувати передумови та розкрити фітоценотичні і фізіономічні підходи (принципи) створення стійких високодекоративних фітоценозів рододендронових садів в умовах України.

Матеріали та методи дослідження. Для дослідження можливостей формування садів рододендронів в умовах України використано відомості про інтродукцію роду в ботанічних установах різних регіонів України та результати біолого-екологічних особливостей його представників, отримані на основі досліджень авторів О. М. Ванзар (1998), А. У. Зарубенка (2006), Г. В. Тимчишин (2003) і власних досліджень (Vegera, 2006).

Методика дослідження базувалась на загальних принципах (підходах) створення садів в умовах Укра-

Інформація про авторів:

Вегера Людмила Василівна, канд. біол. наук, ст. науковий співробітник. Email: Iyudmila1vegera@gmail.com

Мазуренко Валентина Дмитрівна, канд. біол. наук, ст. викладач. Email: mvd-18@ukr.net

Цитування за ДСту: Вегера Л. В., Мазуренко В. Д. Створення стійких фітоценозів рододендронових садів в умовах України: передумови та підходи. Науковий вісник НлТУ України. 2018, т. 28, № 6. С. 14-17.

Citation APA: Vegera, L. V., \& Mazurenko, V. D. (2018). Creation of sustainable phytocenoses of rhododendron gardens in Ukraine: preconditions and approaches. Scientific Bulletin of UNFU, 28(6), 14-17. https://doi.org/10.15421/40280602 
їни, наведених В. П. Кучерявим (Kucheriavyi, 2005), котрий під час розроблення композиційних картин на певному ландшафті виділяе низку принципів підбору рослин. Матеріали цієї роботи є продовженням публікації (Vegera \& Mazurenko, 2018), в якій розкрито екологічний підхід створення садів рододендронів в умовах України, оскільки їх життєздатність повністю залежить лише за певних умов росту. Проте багаторічний досвід зарубіжних і вітчизняних дендрологів доводить, що під час створення садів, у яких рододендрони є домінантою, потрібно дотримуватись принципів декоративного садівництва і паркового мистецтва, які належать безпосередньо до цієї групи рослин (Kondratovych, 1981; Aleksandrova, 2004). Тому, на нашу думку, варто приділити увагу фізіономічному (декоративно-біологічному) та фітоценотичному принципам створення садів за участю рододендронів (Kondratovych, 1981; Kucheriavyi, 2005).

Результати дослідження та їх обговорення. Відомо, що у природній флорі України поширено тільки два види рододендрона - Rh. luteum Sweet i Rh. kotschyi Simonk. Однак, на основі опрацьованих літературних джерел, виявлено передумови для успішного створення садів рододендронів 3 участю цілої низки стійких видів, форм і сортів в умовах України. Вони грунтуються на експериментальних дослідженнях в умовах північного i західного регіонів України, проведених в різних ботанічних установах. Так, у ботанічному саду ім. О. В. Фоміна Київського національного університету ім. Тараса Шевченка (понад 40-літній досвід) росте понад 160 таксонів рододендронів відкритого грунту різного географічного походження; у ботанічному саду Львівського університету ім. Івана Франка (понад 50-літній досвід) - 96 таксонів; у Національному ботанічному саду ім. М. М. Гришка (понад 60-літній досвід) - 90 таксонів; в умовах Північної Буковини в ботанічному саду Чернівецького національного університету ім. Ю. Федьковича росте 40 таксонів рододендронів (Zarubenko, 2006; Tymchyshyn, 2003; Vanzar, 1998). Також ростуть невеликі колекції рододендронів у вигляді моносадів у ботанічних установах Ужгорода, Львова, Кременця, Хоросткова (Тернопільська обл.) (Zarubenko, 2006). Серед парків у регіоні південного Правобережного Лісостепу України (ПЛУ) осередком культивування і розповсюдження рододендронів став Національний дендрологічний парк "Софіївка" НАН України (Умань), де інтродуковано понад 60 видів, форм та сортів названого роду (Vegera, 2014). У регіоні центрального ПЛУ заплановано створення експозиційної ділянки моносаду рододендронів у Державному дендрологічному парку "Олександрія" (Біла Церква) (Boiko \& Krivdjuk, 2014). Менші моносади рододендронів відомі в інших ботанічних установах України, зокрема в ботанічних садах Житомира, Ужгорода, Києва (Zarubenko, 2006).

Як зауважено, перші сади рододендронів на теренах України виникли у XX ст. саме в ботанічних установах. Унаслідок інтродукційної роботи ботанічних садів i дендропарків відбувалось стрімке збільшення колекційного фонду рослин родини Ericaceae DC. та його найчисленнішого роду Rhododendron.

Основні підходи створення, розвитку та збереження сучасних рододендронових садів в Україні висвітлено фрагментарно, адже тут культура роду Rhododendron $€$ відносно молодою (Vegera, 2006; Zarubenko, 2006, Zarubenko, Tymchyshyn \& Shumyk, 2004).

У країнах $з$ наближеними до оптимальних екологічними умовами, а саме 3 вологішим, а тому зі сприятливішим для росту рододендронів кліматом, діапазон використання рододендронів, як цінного матеріалу для озеленення, де вони виступають як домінантний елемент, надзвичайно широкий: вони придатні для облаштування не лише громадських місць, де рослини зазвичай розміщуються великими групами, а також для солітерних насаджень, для створення насаджень біля будівель, пансіонатів, будинків відпочинку, для озеленення санаторіїв, дач, меморіальних зон, альпінаріїв тощо (Kondratovych, 1981).

Фітоценотичний принцип підбору рослин для формування насаджень базується на фітоценологічному вченні про сумісний ріст рослин у природі, їх склад i взаємовплив. Цей принцип потрібно враховувати під час створення моносаду рододендронів, особливо під час вибору його розміщення у ландшафтах, де вже ростуть зрілі дерева. $€$ помилкою висаджування рододендронів близько або під деревними породами 3 поверхневою кореневою системою (клен, в'яз, граб, верба, ясен, каштан, туя), оскільки поверхнева коренева система кущів не може конкурувати за вологу й елементи живлення $з$ кореневою системою дерев. Густа тінь від намету гілок листопадних дерев призводить до порушення такого важливого екологічного фактору для розвитку рододендронів, як освітлення, що у цьому випадку призводить до відсутності закладання квіткових бруньок. Таке співтовариство деревних порід різко знижує декоративність рододендронів і саду загалом.

У природних умовах рододендрони найчастіше трапляються як підлісок у соснових, модринових, кедрово-модринових, дубових, вільхових лісах, тому у культурних ценозах пейзажні картини рододендрового саду бажано створювати насамперед 3 названими деревними породами (Kondratovych, 1981).

В основу фізіономічного або декоративно-біологічного принципу покладено гармонійне поєднання рослин у саду. Під час добору рододендронів за фізіономічним принципом рослини потрібно класифікувати за силою росту та формою крони кущів, сезонною динамікою: тривалістю листяного стану, формою та величиною листкових пластинок, літнім і осіннім забарвленням листків, часом, тривалістю і рясністю цвітіння, кольором і розміром квіток і суцвіть, тобто потрібно враховувати біологічні особливості видів, форм тощо. Застосування перерахованої вище класифікації під час формування композицій дає змогу створити сади, які справлятимуть неповторне враження на глядача. На основі власного досвіду підтримуємо думку Р. Я. Кондратовича щодо дотримання біологічного принципу, про те, що його потрібно розглядати у комплексі з іншими принципами, а зокрема 3 екологічним. Так, наприклад, така біологічна особливість різних видів рододендронів, як інтенсивність цвітіння значно залежить від умов освітлення та інших екологічних факторів зовнішнього середовища (Aleksandrova, 2001; Vegera, 2014; Kondratovych, 1981).

Фізіономічний принцип особливого значення набуває під час створення солітерних і групових насаджень. Для поодиноких посадок М. С. Александрова рекомендує використовувати рододендрони понад 2 м заввишки 
та які здатні розростатись у ширину. Зазвичай такі кущі мають гарну форму куща, соковиті темно-зелені листки та яскраві квітки, зібрані у щільні суцвіття. Під час садіння рододендронів у групових насадженнях потрібно враховувати, що декоративніше виглядають види і сорти одного строку цвітіння та використовувати як гармонічні, так і контрастні поєднання кольорів (Aleksandrova, 2001).

У культурних ценозах під час створення садів за участі рододендронів можна застосувати поєднання 3 формами ялівців козацького, горизонтального і віргінського, форм ялини звичайної і сизої, сосни звичайної і гірської, тису ягідного, канадського і гострокінцевого. Восени жовті, оранжеві, червоні, багряні листки листопадних рододендронів гармонійно поєднуються зі зеленню хвойних порід. Поєднання рододендронів $з$ вереском, ерікою, гортензією, форзицією, вейгелою надає саду ошатного вигляду. 3 вічнозелених листяних порід супутніми породами можуть бути бересклет, андромеда, гаультерія, кизильник, леукотоя. Водночас зелені листки вічнозелених та напіввічнозелених рододендронів $\epsilon$ гарним фоном для рослин родини цибулевих (нарциси, тюльпани, підсніжники, проліски, шафран, мускарі), грунтопокривних рослин (очитки, іберис, каменеломки, гвоздики), папоротей (щитівник, адіантум, цістоптеріс) (Aleksandrova, 2004, Kondratovych, 1981).

Висновки. З'ясовано, що передумовами успішного створення садів рододендронів в умовах України $є$ введення їх у культуру та створення високодекоративних композицій і садів 3 їх участю у різних регіонах України, зокрема у містах: Київ, Львів, Чернівці, Умань, Житомир та ін. Основними місцями їх зосередження $є$ ботанічні сади і дендропарки.

Висвітлено такі принципи (підходи) створення садів рододендронів в Україні, як фітоценотичний і фізіономічний (декоративно-біологічний). Отримані результати експериментальних досліджень щодо влаштування садів рододендронів у ботанічних установах різних регіонів України доводять потреба розглядати і керуватися названими принципами у комплексі, беручи до уваги екологічний принцип. Лише за комплексного дотримування всіх розглянутих підходів можна створити стійкі фітоценози рододендронових садів та забезпечити їх високу декоративність та адаптаційні властивості рослин в умовах України.

\section{Перелік використаних джерел}

Aleksandrova, M. S. (2001). Rododendrony. Moscow: ZAO "Fiton+". [In Russian].

Aleksandrova, M. S. (2004) Rododendrony. Moscow: Kladez-Buks. [In Russian].

Boiko, N. S., \& Krivdjuk, Yu. N. (2014). Perspektivy sozdanija jekspozicionnogo uchastka "Sad Rododendronov" v dendroparke "Aleksandrija" NANU. Perspektivy introdukcii dekorativnyh rastenij $v$ botanicheskih sadah $i$ dendroparkah. Simferopol: Krymskij federalnyj un-t im. V. I. Vernackogo. [In Russian].

Kohno, M. A. (Ed.) (2002). Dendroflora Ukrayiny. Dykorosli $j$ kultyvovani dereva i kushhi. Pokrytonasinni. Part II. Dovidnyk. Kyiv: Fitosociocentr. [In Ukrainian].

Kondratovych, R. Ya. (1981). Rododendrony $v$ Latviyskoy SSR: biologicheskie osobennosti kultury. Riga: Zinatne. [In Russian].

Kucheriavyi, V. P. (2005). Ozelenennia naselenykh mists. Lviv: Svit. [In Ukrainian].

Tymchyshyn, H. V. (2003). Biolohiia ta osoblyvosti kultury Rhododendron L. na Zakhidnomu Podilli. Abstract of Candidate Dissertation for Biology Sciences (03.00.05 - Botany). Kyiv. 16 p. [In Ukrainian].

Vanzar, O. M. (1998). Introduktsiia rododendroniv u Pivnichnii Bukovyni. Abstract of Candidate Dissertation for Biology Sciences (03.00.05 - Botany). Kyiv. 18 p. [In Ukrainian].

Vegera, L. V. (2006). Bioekologichni osoblyvosti ta kultura rododendroniv $v$ umovah Pravoberezhnogo Lisostepu Ukrayiny. Uman: ALMI. [In Ukrainian].

Vegera, L. V. (2014). Praktychni rekomendaciyi shhodo pidvyshhennya zymostijkosti introducentiv rodu Rhododendron L. $v$ Pravoberezhnomu Lisostepu Ukrayiny. Uman: VPCz "Vizavi". [In Ukrainian].

Vegera, L. V., \& Mazurenko, V. D. (2018). Vplyv ekologichnyh umov na stijkist sadiv rododendroniv $v$ umovah introdukciyi. Biologichni doslidzhennya. Zhytomyr: PP "Ruta". 246 p. [In Ukrainian].

Zarubenko, A. U. (2006). Kultura rododendroniv v Ukraini. Kyiv: Vydavnycho-polihrafichnyi tsentr "Kyivskyi universytet". [In Ukrainian].

Zarubenko, A. U., Tymchyshyn, G. V., \& Shumyk, M. I. (2004). Metodychni rekomendaciyi $z$ rozmnozhennya ta kultyvuvannya rododendroniv $v$ Ukrayini. Kyiv: Fitosociocentr. [In Ukrainian].

\title{
Л. В. Вегера1, В. Д. Мазуренко 2 \\ ${ }^{1}$ Начиональный дендрологический парк "Софиевка", НАН Украины, г. Умань, Украина \\ ${ }^{2}$ Уманский национальный университет садоводства, г. Умань, Украина
}

\section{СОЗДАНИЕ УСТОЙЧИВЫХ ФИТОЦЕНОЗОВ РОДОДЕНДРОНОВЫХ САДОВ В УСЛОВИЯХ УКРАИНЫ: ПРЕДПОСЫЛКИ И ПОДХОДЫ}

\begin{abstract}
Определены основные предпосылки создания устойчивых высокодекоративных фитоценозов рододендроновых садов в почвенно-климатических условиях Украины. Обобщены данные литературных источников и собственных исследований по созданию садов рододендронов в Украине. Отмечено, что первые сады рододендронов на территории Украины возникли в $\mathrm{XX}$ в. в ботанических садах как следствие интродукционной работы ботанических учреждений, когда происходило стремительное увеличение коллекционного фонда древесных растений семейства Ericaceae DC., в том числе и его многочисленного рода Rhododendron L. Освещены такие принципы формирования и создания садов с участием рододендронов, как фитоценотический и физиономический. Фитоценотический принцип подбора растений для формирования насаждений базируется на фитоценологическом учении о совместном росте растений в природе, их составе и взаимовлиянии. В культурных ценозах Украины пейзажные картины рододендрового сада желательно создавать в первую очередь с теми древесными породами, с которыми они, как подлесок, растут в естественных условиях, а именно: с сосной, лиственницей, дубом, ольхой и другими породами с глубокой корневой системой. При подборе рододендронов по физиономическому принципу необходимо учитывать силу роста и форму кроны кустов, сезонную динамику. Однако только комплексное применение названных принципов в сочетании с экологическим может способствовать повышению декоративности сада и адаптационных свойств рододендронов в условиях Украины.
\end{abstract}

Ключевые слова: фитоценотический, физиономический принципы; Rhododendron L.; применение; адаптационные свойства. 


\section{CREATION OF SUSTAINABLE PHYTOCENOSES OF RHODODENDRON GARDENS IN UKRAINE: PRECONDITIONS AND APPROACHES}

A major role in the cultural flora enrichment of Ukraine with the new introduced taxa of shrubbery bushes belongs to rhododendrons. The purpose of this work is to find out the prerequisites for the establishment of sustainable highly decorative phytocenoses of rhododendron gardens and to disclosure phytocoenoses and physiognotic approaches to garden formation in Ukraine. To study the possibilities for the rhododendron garden formation in Ukraine the introduction information on the genus in the botanical establishment of different Ukrainian regions and the biological and ecological peculiarities of its representatives were used. They were obtained on the bases of the research by such authors as O. M. Vanzar (Vanzar,1998), A. U. Zarubenko (Zarubenko, 2006), G. V. Tymchyshyn (Tymchyshyn, 2003), and own reseaches (Vegera, 2006). The methodology on the rhododendron garden creation is based on the general principles of the garden creation in Ukraine given by V. P. Kucheryaviy (Kucheryaviy, 2005) given in particular physiognomis (decorative and biological) and phytocenotic principals. These article materials are the continuation of the publication (Vegera, Mazurenko, 2018) which disclosed the ecological approaches for the rhododendron garden creation in Ukraine. It is stated that the first gardens arose in the last century as the introduction result of botanical gardens and arboretums. It happened when there was a rapid increase in the collection fund of the family Ericaceae DC. and its most numerous family Rhododendron L. As a consequence, a number of resistant species, forms and varieties suitable for garden creation have been identified. The phytocenotic principle of plant selection in rhododendron gardens is based on the phytocenotic study of the compatible rhododendron growth with the other woody plants in nature, their composition and the mutual influence. The rhododendron selection according to the physiognomic principles are classified according to the growth force and the crown shape of bushes, the color, the leaf blade size, the flowers and thorns size, the seasonal dynamic: the length of the leaf stage, the shape and size of the leaf blades, the late autumn leaf color, time and duration of flowering. Consequently, the prerequisites for the successful creation of rhododendron gardens in Ukraine are their introduction into the culture and the creation of highly decorative compositions with their participation in botanical gardens and arboretums in different regions of Ukraine. The main principles of rhododendron garden collection are the contribution to their better adaptation and decoration.

Keywords: phytocenotic; physiognomis; principals; garden formation; genus Rhododendron L.; complex observance; adaptive properties; decoration. 